Reprogramming of somatic cells to induced pluripotent stem cells (iPSCs) requires profound alterations in the epigenetic landscape. During reprogramming, a change in chromatin structure resets the gene expression and stabilises self-renewal. Reprogramming is a highly inefficient process, in part due to multiple epigenetic barriers. Although many epigenetic factors have already been shown to affect self-renewal and pluripotency in embryonic stem cells (ESCS), only a few of them have been examined in the context of dedifferentiation. In order to improve current protocols of iPSCs generation, it is essential to identify epigenetic drivers and blockages of somatic cell reprogramming.

Key words: induced pluripotent stem cells, epigenetics, chromatin modifications, DNA methylation.

Contemp Oncol (Pozn) 2015; 19 (1A): A30-A38 DOI: $10.5114 /$ wo. 2014.47135

\section{Epigenetic mechanisms of induced pluripotency}

\author{
Marta Gładych ${ }^{1,2}$, Anastazja Andrzejewska ${ }^{1,2}$, Urszula Oleksiewicz ${ }^{1,2}$, \\ Marcos R.H. Estécio ${ }^{3}$
}

${ }^{1}$ Department of Cancer Immunology, Chair of Medical Biotechnology, Poznan University of Medical Sciences, Poznan, Poland

${ }^{2}$ Laboratory of Gene Therapy, Department of Cancer Immunology, Greater Poland Cancer Centre, Poznan, Poland

${ }^{3}$ Department of Molecular Carcinogenesis, Division of Basic Science Research, University of Texas MD Anderson Cancer Center, Houston, TX, USA

\section{Introduction}

Reprogramming somatic cells to induced pluripotent stem cells (iPSCs) that can differentiate into any cell type, similarly to embryonic stem cells (ESCS), paved new avenues for regenerative medicine, disease modelling, and drug screening [1]. The process might be induced with nuclear transfer [2, 3], cell fusion [4], or forced expression of transcription factors (i.e. OSKM: Oct4, Sox2, Klf4, c-Myc [5], or other combinations [6]). All of these methods initiate a cascade of transcriptional and epigenetic changes that direct cells toward pluripotency $[7,8]$.

Epigenetic machinery combines multiple networks of proteins that are interconnected through functional and physical interactions to write, read, and edit chromatin information, thus allowing dynamic regulation of chromatin status and gene expression. Adult somatic cells are characterised by a stable chromatin environment, responsible for silencing genes that are not specific for a particular cell type. Compared to lineage-committed cells, pluripotent stem cells possess a unique epigenetic profile enriched for open, active chromatin modifications, including $\mathrm{H} 3 \mathrm{~K} 4 \mathrm{me} 3, \mathrm{H} 3 \mathrm{~K} 36 \mathrm{me} 3$, histone acetylation, and hypomethylated DNA (Fig. 1). These marks are frequently found within the regions of pluripotency genes. In contrast, tightly composed heterochromatin is marked with $\mathrm{H} 3 \mathrm{~K} 27 \mathrm{me} 3, \mathrm{H} 3 \mathrm{~K} 9 \mathrm{me} 3$, and hypermethylated DNA and localises to multiple tissue-specific genes and repetitive elements. Besides, pluripotent stem cells contain increased levels of bivalent domains marked both with $\mathrm{H} 3 \mathrm{~K} 4 \mathrm{me} 3$ and H3K27me3 at differentiation-related genes. The genes marked with bivalent domains are in a poised state, which means that their expression can be quickly turned on or stably silenced via erasure of H3K27me3 or H3K4me3, respectively. Disturbance of such a delicate balance can result in reduced self-renewal, enhanced differentiation of pluripotent cells, and/or impeded reprogramming of somatic cells to iPSCs [8-11] (Table 1). Hereby, we aim to review current knowledge and understanding of the epigenetic profile, mechanisms, and modifiers that drive or block somatic cell reprogramming.

\section{DNA methylation}

DNA methylation profile in induced pluripotent cells

The content of DNA methylation changes dramatically during gametogenesis and cellular differentiation, with near complete erasure in progenitor germ cells and waves of re-methylation during germ cell maturation and fertilisation [12]. Early observations, most based on 5-methylcytosine by immunostaining, indicated that the sperm's genome undergoes dynamic demethylation in the zygote (which occurs without new DNA synthesis) [13], while the embryo's genome loses DNA methylation passively along cellu- 
Heterochromatin (pluripotency genes)

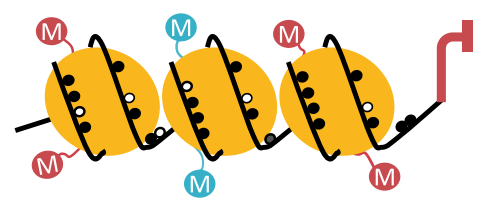

Pluripotency induction

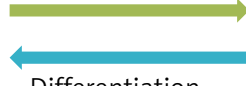

Euchromatin (tissue-specific genes)
Differentiation

Euchromatin (pluripotency genes)

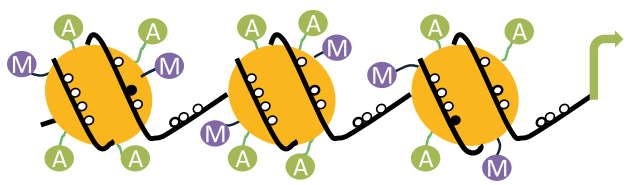

Bivalent chromatin (differentiation genes)

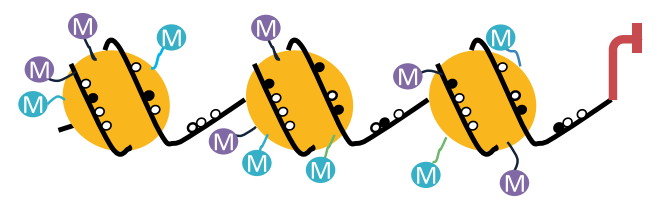

Heterochromatin (tissue-specific genes)

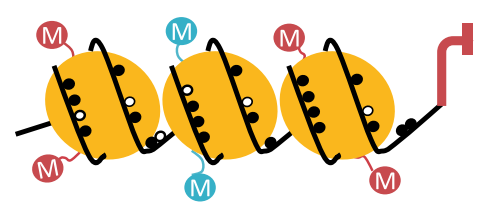

- Methylated cytosine

O Unmethylated cytosine

Fig. 1. Schematic representation of the chromatin rearrangements occurring during somatic cell reprogramming and differentiation of pluripotent stem cells

lar divisions [14]. Refinements of these observations have been provided by single-base resolution assays to measure 5 -methylcytosine $[15,16]$, but the core information that DNA methylation is dynamically changed during fertilisation and development remains true. The importance of DNA methylation during development was also reinforced by several studies showing that mice lacking any of the DNA methyltransferases (Dnmt1, Dnmt3a, and Dnmt3b) are not viable or die within a few weeks [17-20]. These observations are evidence that epigenetic events are key to cellular differentiation, and it is logical to extrapolate that these same events have to be reversed during induced reprogramming. Indeed, resetting of the DNA methylation profile appears to be an important part of dedifferentiation. Treatment of somatic cells with agents that block the activity of DNA methyltransferases (e.g. 5-aza-cytidine) contributes to the increased efficiency of iPSC generation $[21,22]$. What is more, it facilitates the transition of partially reprogrammed cells into a full state of pluripotency [22].

In contrast, somatic cells show stable DNA methylation. Once the tissue-specific patterns of DNA methylation are established, they will remain virtually unmodified throughout life, with the exception of cellular transformation by carcinogenesis. The paradigm that differentiation is a one-way process was challenged with the description of reprogramming by somatic cell nuclear transfer, initially described using frog cells [2] and later in mammals [3]. A revolution in the field of cellular reprogramming occurred with the description of induced pluripotent (iPS) stem cells [5]. The initial report of iPS cells identified four genes that, when re-expressed in differentiated mouse cells, were suf- ficient to induce dedifferentiation: Oct4, Sox2, Klf4, and cMyc. The process was shown to be reproducible in human cells using the same four factors [23], and combinations of alternative genes were also described (for example, the use of Nanog and Lin28 in place of Klf4 and Myc) [6].

Oct4 is highly expressed in embryonic stem cells, and it shows decreased expression with differentiation and concomitant increase in DNA methylation of its promoter region. A fundamental characteristic of iPS cells is the re-activation of the endogenous Oct4 gene and other pluripotency factors (like Nanog). This is accompanied by demethylation of their gene promoters, as shown in the original iPSCs [5]. Further research extended the DNA methylation profiling of iPSCS genome-wide, and iPSCS globally present diverse similarities to ESCs: the genome of iPSCs is methylated to a higher extent than the genome of somatic cells; non-CG methylation (which is basically inexistent in somatic cells but abundant in ESCS) is found in iPSCs, and somatic unmethylated genes that are methylated in ESCs revert to a methylated state (and also the reverse situation, i.e. somatic hypermethylated genes can be reprogrammed to an unmethylated state) [24, 25].

Among the differences, several groups have described DMRs (differentially methylated regions) that are unique to iPSCs compared to ESCs. Using MethylC-Seq to evaluate DNA methylation at near whole genome scale, Lister et al. [24] identified over a thousand DMRs in the CG context (CG-DMRs), comprising in total $1.68 \mathrm{Mb}$ and ranging in length from $1 \mathrm{~kb}$ to $11 \mathrm{~kb}$. They also evaluated DMRs in the non-CG context and found that these are less numerous (29) but much greater in length (typically spanning 
Table 1. Epigenetic modifiers and their role in somatic cell reprogramming and biology of pluripotent stem cells

\begin{tabular}{|c|c|c|}
\hline Epigenetic modifier & Reprogramming to iPSCs & ESC biology \\
\hline esBaf (Swi/Snf complex) & EsBaf overexpression increases reprogramming [70] & EsBaf maintains pluripotency $[90,91]$ \\
\hline Chd1 & Chd1 depletion hinders reprogramming [73] & $\begin{array}{l}\text { Chd1 depletion augments heterochromatisation, } \\
\text { reduces self-renewal properties and leads to } \\
\text { improper differentiation [73] }\end{array}$ \\
\hline Mbd3 (NuRD complex) & $\begin{array}{l}\text { Conflicting data: } \mathrm{Mbd} 3 \text { depletion improves } \\
\text { reprogramming [82], even to } 100 \% \text { efficiency [81], } \\
\text { but is indispensable for iPS generation [83] }\end{array}$ & $\begin{array}{l}\text { Mbd3 depletion up- [92] and downregulates } \\
\text { certain pluripotency genes and impedes } \\
\text { differentiation capacity [93] }\end{array}$ \\
\hline Mbd2 (NuRD complex) & $\begin{array}{l}\text { Mbd2 silencing increases reprogramming due to } \\
\text { derepression of Nanog [79], overexpression of } \\
\text { isoform Mbd2c increases reprogramming [80] }\end{array}$ & $\begin{array}{l}\text { Overexpression of isoform } \mathrm{Mbd} 2 \mathrm{a} \text { leads to } \\
\text { differentiation [80] }\end{array}$ \\
\hline Hdac (NuRD complex) & $\begin{array}{l}\text { Hdac inhibitors increase reprogramming } \\
{[21,75-78]}\end{array}$ & $\begin{array}{l}\text { Hdac1 deletion induces meso- and ectodermal } \\
\text { differentiation [94] }\end{array}$ \\
\hline Ino family & $\begin{array}{l}\text { Ino80 depletion decreases reprogramming } \\
\text { efficiency [72] }\end{array}$ & $\begin{array}{l}\text { Tip60-p400 silencing impairs self-renewal and } \\
\text { differentiation [95] }\end{array}$ \\
\hline $\begin{array}{l}\text { Wdr5 (H3K4 methyltransferase } \\
\text { Set/Mll complex) }\end{array}$ & Wdr5 knockdown decreases reprogramming [55] & $\begin{array}{l}\text { High Wdr5 expression correlates with pluri- } \\
\text { potency; loss of Wdr5 induces differentiation [55] }\end{array}$ \\
\hline Kdm5b (H3K4me demethylase) & $\begin{array}{l}\text { Kdm5b knockdown enhances reprogramming } \\
{[56]}\end{array}$ & $\begin{array}{l}\text { Highly expressed in ES [96], Kdm5b silencing } \\
\text { evokes differentiation [97] }\end{array}$ \\
\hline $\begin{array}{l}\text { Jhdm1b (H3K36me } \\
\text { demethylase) }\end{array}$ & $\begin{array}{l}\text { Jhdm1b overexpression enhances reprogramming } \\
{[57,58]}\end{array}$ & Highly expressed in ES [57] \\
\hline $\begin{array}{l}\text { Ezh2, Eed, Suz12 (H3K27 } \\
\text { methyltransferase complex } \\
\text { PRC2) }\end{array}$ & $\begin{array}{l}\text { Ezh2 overexpression enhances }[60,62] \text {, } \\
\text { while Ezh2, Eed, Suz12 silencing reduces } \\
\text { reprogramming efficiency [59] }\end{array}$ & $\begin{array}{l}\text { Eed depletion results in loss of pluripotency [98], } \\
\text { ESCs lacking Eed, Suz12 are unable to reprogram } \\
\text { B cell to pluripotency [61] }\end{array}$ \\
\hline Utx (H3K27me2/3 demethylase) & Utx knockdown impairs iPS formation [64] & Utx knockout does not influence pluripotency [64] \\
\hline $\begin{array}{l}\text { Ehmt2/G9a (H3K9 } \\
\text { methyltransferase) }\end{array}$ & $\begin{array}{l}\text { Ehmt2/G9a repression increases }[21,68] \text { or } \\
\text { moderately decreases }[59] \text { reprogramming }\end{array}$ & $\begin{array}{l}\text { Loss of Ehmt2/G9a impedes differentiation } \\
{[99,100]}\end{array}$ \\
\hline $\begin{array}{l}\text { Setdb1 (H3K9 } \\
\text { methyltransferase) }\end{array}$ & $\begin{array}{l}\text { Setdb1 inhibition increases [65] or moderately } \\
\text { decreases [59] reprogramming }\end{array}$ & $\begin{array}{l}\text { SetDB1 directs retroviral silencing in ESCs } \\
{[101,102] \text {, its repression induces differentiation, }} \\
\text { especially into the trophoectoderm lineage } \\
{[103-106]}\end{array}$ \\
\hline $\begin{array}{l}\text { Suv39H1/2 (H3K9 } \\
\text { methyltransferase) }\end{array}$ & $\begin{array}{l}\text { Suv } 39 \mathrm{H} 1 / 2 \text { downregulation increases } \\
\text { reprogramming }[59,67]\end{array}$ & $\begin{array}{l}\text { Suv39H represses LINE and ERV retroelements } \\
\text { [107] }\end{array}$ \\
\hline H3K9 demethylases & $\begin{array}{l}\text { Loss of } \mathrm{Kdm} 3 \mathrm{a}, \mathrm{Kdm} 3 \mathrm{~b}, \mathrm{Kdm} 4 \mathrm{~b}, \mathrm{Kdm} 4 \mathrm{c} \text { decreases } \\
\text { reprogramming }[65,69] \text {; } \mathrm{Kdm} 4 \mathrm{~b} \text { overexpression } \\
\text { promotes conversion from pre-iPSCs to iPSCs [65] }\end{array}$ & $\begin{array}{l}\text { Loss of Kdm3a, Kdm4b, Kdm4c evokes loss of } \\
\text { self-renewal and differentiation }[69,108]\end{array}$ \\
\hline Dot1l (H3K79me demethylase) & Dot1l silencing facilitates reprogramming [59] & $\begin{array}{l}\text { Dot1l deficiency impairs differentiation due to } \\
\text { cell proliferation defects }[109,110]\end{array}$ \\
\hline
\end{tabular}

megabases). The majority of both types of DMRs were typically hypomethylated in iPS compared to ES cells. Another significant difference is that key lineage-specific methylated genes appear to be resistant to resetting, at least in low-passage iPS cells [26]. Differences in DNA methylation appear to be attenuated by continued passaging of iPS cells [27].

\section{Genomic imprinting}

Genomic imprinting is a phenomenon resulting from epigenetic marking of an allele depending on its parental origin, which consequently leads to gene expression from either maternal or paternal locus. Many imprinted genes function as growth regulators, so adequate imprinting is crucial for development, especially at its early stages. Imprinting marks are erased in primordial germ cells, re-es- tablished in the maturing gametes, and maintained during global DNA demethylation post-fertilization and thereafter [28]. During reprogramming, the cells also undergo DNA demethylation, however, iPSCs generally retain proper imprinting [29]. Nevertheless, a few reports demonstrated that a small percentage of iPS colonies may show variable loss of imprinting, leading either to hyper- or hypomethylation of imprinting control regions and subsequent change in gene expression [30-32]. The most apparent exception to this schema is represented by the Dlk1-Dio3 region, which is frequently hypermethylated and therefore repressed in iPSCS [32-34]. Remarkably, the iPSCs with downregulated Dlk1-Dio3 cluster have reduced ability to fully contribute to chimeras [33-35]. Such a phenomenon might be prevented with ascorbic acid, which was recently shown to inhibit the silencing of genes within the Dlk1- 
Dio3 region during reprogramming by interfering with de novo DNA methyltransferase, Dnmt3a [36].

\section{X-inactivation}

An important feature in determining the state of pluripotency is the reactivation of the inactive $X$ chromosome in female cells. This phenomenon occurs relatively late during reprogramming, reflecting the activation of endogenous transcription factors (i.e. Nanog and Oct4) [37]. Xist (X-inactive specific transcript) large, non-coding RNA molecule is a regulating agent of cis-repression responsible for the $\mathrm{X}$-inactivation. This process involves accumulation of inactive chromatin marker, H3K27me3. In mouse iPSCS reactivation of $X$ chromosome is complete and the expression of Xist is not observed. It was proposed that transcription factors Oct4, Sox2, and Nanog could bind to a coding region of Xist and downregulate its expression [38]. However, the process in human cells is more complicated. Female hESCs are characterised by a large variety of epigenetic status of $X$ chromosome. The same phenomenon was observed in the case of female hiPSCs. There are conflicting results showing that in some cases X-chromosome inactivation is still present in iPSCs [39, 40], while other researchers have demonstrated full $X$-reactivation $[41,42]$. The reason for this event seems to be the length of iPS colony culture. At first the $\mathrm{X}$ chromosome remains inactive, but it becomes activated upon the subsequent passages $[43,44]$.

\section{DNA demethylation mechanisms}

Global pattern of DNA methylation is erased during early development [12]. Passive demethylation occurs during DNA replication, whereas active demethylation involves oxidative activity of Tet enzymes: Tet1/2/3, which are responsible for hydroxylation of 5-methylcytosine $(5 \mathrm{mC})$ to 5 -hydroxymethylcytosine $(5 \mathrm{hmC})$. The hydroxylated form of $5 \mathrm{mC}$ might be further converted to unmethylated cytosine through subsequent cell divisions or base-excision repair mechanisms [45]. This leads to the generation of an open chromatin environment that allows an access of transcription factors (such as Nanog and Esrrb) to the promoters of genes involved in pluripotency $[46,47]$. Catalytic activity of Tet1/2 in cooperation with Nanog enhances reprogramming efficiency [48]. It was proposed that Tet1 is recruited by Nanog to pluripotency-associated genes and facilitates their expression by increasing $5 \mathrm{hmC}$ levels [48]. In concordance with this notion, the level of $5 \mathrm{hmC}$ and Tet1 activity was shown to be upregulated during the course of dedifferentiation [47, 49]. Moreover, recent reports indicate that loss of the proteins involved in oxidative demethylation abrogates mesenchymal-to-epithelial transition, an event occurring at the initial stages of reprogramming [50]. It seems that erasing DNA methylation promotes expression of pluripotency-related genes that were silenced through hypermethylation in somatic cells.

\section{Chromatin modifications}

Euchromatization occurring during generation of iPSCS involves multiple factors that affect higher chromatin struc- ture, nucleosome composition, and location, as well as post-translational histone modifications (Fig. 2) [10]. Acetylation of histones decreases their interaction with DNA, whereas histone methylation creates patterns that might affect the binding or activity of chromatin rearranging complexes. Proteins that are involved in histone modifications interact with each other and with the DNA methylation machinery creating a complex regulatory network [51].

\section{Active histone modifications}

\section{H3K4 methylation}

The initiation phase of reprogramming evokes changes in the expression profile of multiple genes. Interestingly, both up- and downregulation of expression affects the genes, whose promoters in differentiated cells are associated with a permissive chromatin environment marked mainly by $\mathrm{H} 3 \mathrm{~K} 4 \mathrm{me} 3$ [52]. This indicates that initiation of reprogramming is tightly linked with an open chromatin state. Another marker of active chromatin, H3K4me2, surrounds both gene promoters and enhancers. Its enrichment does not correlate with immediate upregulation of gene expression during the first phase of reprogramming. Instead, H3K4me2 marks developmental and pluripotency-related genes, which become transcriptionally active at the latter stage of reprogramming [52]. Trimethylation of $\mathrm{H} 3 \mathrm{~K} 4$, which is generally correlated with gene activation, is catalysed by Trithorax group (TrxG) protein complex [53]. In mammalian cells histone methyltransferase complex Set/ Mll, a homologue of TrxG, is responsible for methylation of $\mathrm{H} 3 \mathrm{~K} 4$. To be catalytically active, Set/MII requires core subunits such as Wdr5 [54]. It has been shown that Wdr5 becomes overexpressed during iPSCs generation [55]. IPSCs generation is impaired after Wdr5 knockdown, and this effect is most apparent during the initiation phase of reprogramming [55]. This is consistent with the findings that expression of $\mathrm{Kdm} 5 \mathrm{~b}$ is a barrier in the iPS colony formation: Kdm5b belongs to jumonji C-containing protein complexes, a family of demethylases that triggers demethylation of active histone mark $\mathrm{H} 3 \mathrm{~K} 4 \mathrm{me} 1 / 2 / 3$. Erasing $\mathrm{H} 3 \mathrm{~K} 4$ methylation impairs reprogramming, whereas knockdown of Kdm5b enhances efficiency of iPSC generation [56].

\section{H3K36 and H3K79 methylation}

$\mathrm{H} 3 \mathrm{~K} 36 \mathrm{me} 2 / 3$ modification is present across gene bodies that are actively transcribed. Interestingly, global reduction of this mark enhances reprogramming $[57,58]$. Wang et al. demonstrated that overexpression of a H3K36me2 demethylase, Jhdm1b ( $\mathrm{Kdm} 2 \mathrm{~b})$, is sufficient to promote iPS colony formation by Oct4 alone [58]. What is more, it was shown that $\mathrm{Kdm} 2 \mathrm{~b}$ binds promoters of genes that are activated early during reprogramming, including epithelial and pluripotency genes [57]. Another mark of open chromatin structure, methylation of histone $\mathrm{H} 3$ at lysine 79 (H3K79me), positively associates with transcriptionally active genes and negatively associates with genes marked by H3K27me3. As described by Onder et al., inhibition of Dot1l - H3K79 methyltransferase facilitates more efficient loss of H3K79me2 from somatic genes and increases reprogramming potential [59]. 


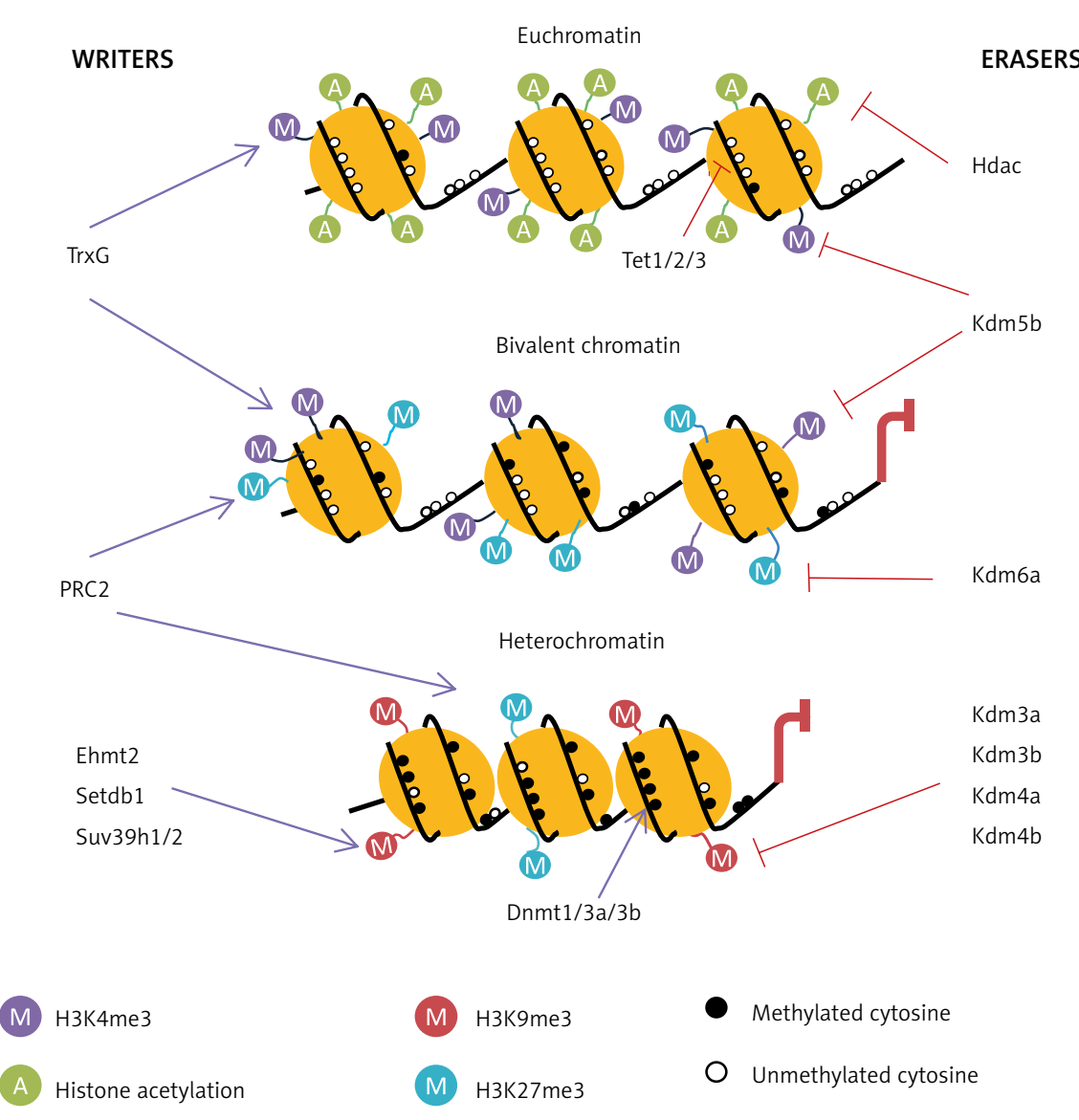

Fig. 2. Epigenetic modifiers responsible for chromatin reorganisation that play a role in reprogramming as drivers or blockages

\section{Repressive histone modifications}

\section{H3K27 methylation}

Downregulation of somatic genes at the early stage of reprogramming is mediated by PRC2 (Polycomb Repressive Complex 2) that deposits a trimethylation mark at K27 of $\mathrm{H} 3$ (H3K27me3). H3K27me3 is associated either with gene silencing or, when co-localised with $\mathrm{H} 3 \mathrm{~K} 4 \mathrm{me} 3$, with bivalent domains. Recent studies revealed that PRC2 components (Ezh2, Eed, and Suz12) are critical to iPSCs generation [59]. It has been shown that loss of these factors reduces reprogramming efficiency [59, 60]. Moreover, ESCS lacking either PRC1 or PRC2 components lose the ability to reprogram B cells to iPSCs upon cell fusion [61]. In another study, Ding et al. observed that Ezh2 expression is induced during the course of reprogramming and is retained at high levels in iPSCs. Consistently with this notion, exogenous overexpression of Ezh2 enhanced reprogramming, while its suppression impaired transition to iPSCs [62]. In contrast, Fragola et al. showed that loss of Ezh2 had little effect on iPSCs generation, despite global decrease in $\mathrm{H} 3 \mathrm{~K} 27 \mathrm{me} 3$ level, due to selective, partial retention of this mark on target genes [63]. Nevertheless, erasing H3K27me3 seems to be an important part of epigenetic reprogramming. For example, the $\mathrm{H} 3 \mathrm{~K} 27 \mathrm{me} 2 / 3$ demethylase Utx (Kdm6a) was shown to be essential for iPSCs generation, although its influence on ES cell maintenance of pluripotency or lineage commitment was marginal [64].

\section{H3K9 methylation}

H3K9 trimethylation canonical function is the promotion of long-range heterochromatisation, and thus, transcriptional silencing. It has been shown in multiple reports that H3K9 methylation machinery acts as a key epigenetic blockade to reprogramming [65-68]. Repression of H3K9 methyltransferases (Ehmt2, Setdb1, Suv39h1/2) results in increased reprogramming efficiency, which is accompanied by decondensation of chromatin $[67,68]$. It has been shown, for example, that transient silencing of Su$\mathrm{v} 39 \mathrm{~h} 1 / 2$ promotes reprogramming at its early stages due to decreased level of $\mathrm{H} 3 \mathrm{~K} 9 \mathrm{me} 3$ within the binding sites of OSKM factors. Thus, loss of H3K9me3 permits an access of OSKM factors to their target regions, including those responsible for pluripotency-related signalling [67]. Consistently with these observations, knockdown of a number of H3K9 demethylases (Kdm3a, Kdm3b, Kdm4a, Kdm4b) blocks reprogramming $[65,69]$, while exogenous overexpression of $\mathrm{Kdm} 4 \mathrm{~b}$ induces conversion of pre-iPSCs to iP. SCs [65].

\section{ATP-dependent chromatin remodelling complexes}

ATP-dependent chromatin-modifying complexes (such as: Swi/Snf, Chd, Ino80, Iswi) induce structural transitions between various chromatin conformations by evicting, re-positioning, or altering the composition of nucleosomes 
[51]. Overexpression of the ESC-specific component of Swi/Snf complex, esBaf, assists reprogramming by facilitating Oct4 binding to its target sites [70]. Also, high levels of Baf subunits (Baf155, Brg1) correlate with higher reprogramming efficiency in liver progenitor cells compared to differentiated hepatocytes, while their knockout impedes reprogramming of liver progenitors [71]. Silencing of another chromatin remodeller, Ino80, decreases dedifferentiation due to reduced recruitment of Oct4 and Wdr5 to promoters of pluripotency genes [72].

More attention has been given to the Chd family ATPases, especially to the components of NuRD complex. Chd1 ATPase is necessary to maintain open chromatin structure in stem cells. Its depletion leads to increased heterochromatisation, decreased self-renewal properties, and reduced iPSCs formation [73]. NuRD functions in cooperation with other factors (PRC2, Lsd1, Oct4, Stat3, p300, and esBaf) to balance pluripotency gene expression and to maintain developmental genes in poised or silent state. NuRD complex contains Mi-2 $\alpha / \beta$ ATPases, Hdac1/2 (histone deacetylases) and Mbd2/3 (methyl-CpG binding domain) proteins that drive chromatin condensation [74]. Chemical inhibition of Hdac boosts iPS colony formation through euchromatization due to global histone acetylation [21, 75-78]. It remains to be elucidated, however, whether other proteins that remain acetylated upon HDACi treatment also support somatic cell reprogramming. Recruitment of NuRD complex to methylated loci is mediated by Mbd2. Mbd2 silencing by overexpressed miR302 cluster enhances iPS generation through reactivation of Nanog [79]. Interestingly, Mbd2 effect on dedifferentiation seems to depend on its splicing isoform because Mbd2c (which does not interact with NuRD) increases reprogramming efficiency [80].

Interesting but conflicting data have come from studies on Mbd3 factor. Rais et al. demonstrated that Mbd3/NuRD depletion renders reprogramming deterministic, because $100 \%$ of the cells become pluripotent [81]. In another study Mbd3 silencing promoted chromatin decondensation at pluripotency genes, thus increasing iPSCs formation efficiency, but not to a deterministic level [82]. In contrast to these reports, it has recently been shown that NuRD complex is indispensable for efficient reprogramming to naïve pluripotent stem cells [83]. These data suggest that the effect of $\mathrm{Mbd} 3$ on reprogramming is dependent on cellular context and timing of Mbd3 knockdown.

\section{Histone variants}

The composition of nucleosomes affects their stability, susceptibility to histone modifications, and thus chromatin structure [11]. Histone variants are expressed in a cell type-specific manner and their arrangement influences gene expression. For example, somatic reprogramming is enhanced by two histone variants: $\mathrm{TH} 2 \mathrm{~A}$ and $\mathrm{TH} 2 \mathrm{~B}$, which are characteristic for oocytes, testis, and zygotes [84]. In contrast, macroH2A2 and macroH2A1 block reprogramming due to the co-occupancy with $\mathrm{H} 3 \mathrm{~K} 27 \mathrm{me} 3$ at the pluripotency and developmental genes [85-88]. These observations remain in agreement with previous studies demonstrating that upon somatic cell nuclear transfer to oocytes, macro$\mathrm{H} 2 \mathrm{~A}$ is rapidly removed from the nucleus [89].

\section{Conclusions}

The role of the proteins involved in the regulation of chromatin status in reprogramming is currently being intensively investigated. It needs to be emphasised, however, that the majority of data reported so far have utilised mouse models. Similar mechanisms should also be tested and validated in human cells. What is more, several studies on epigenetic modifiers provide conflicting data, and these discrepancies need to be addressed. Untangling the interconnectivity of the chromatin remodellers during reprogramming will greatly enhance our understanding of the mechanisms involved in this complex process. It will also allow conscious, targeted usage of specific chemical compounds to boost reprogramming or even substitute OSKM cocktail. Many processes accompanying somatic cell reprogramming to iPSCs occur also during carcinogenic reprogramming. Thus, the knowledge stemming from research on the epigenetic mechanisms in reprogramming might also improve our understanding of cancer biology.

The authors declare no conflict of interest.

This work was supported by the Foundation for Polish Science Welcome program grant No: 2010-3/3 to Maciej Wiznerowicz and UT MD Anderson Cancer Center intramural grants.

\section{References}

1. Robinton DA, Daley GQ. The promise of induced pluripotent stem cells in research and therapy. Nature 2012; 481: 295-305.

2. Briggs R, King TJ. Transplantation of Living Nuclei From Blastula Cells into Enucleated Frogs' Eggs. Proc Natl Acad Sci U S A 1952; 38: 455-63.

3. Wilmut I, Schnieke AE, McWhir J, Kind AJ, Campbell KH. Viable offspring derived from fetal and adult mammalian cells. Nature 1997; 385: 810-3.

4. Tada M, Takahama Y, Abe K, Nakatsuji N, Tada T. Nuclear reprogramming of somatic cells by in vitro hybridization with ES cells. Curr Biol 2001; 11: 1553-8.

5. Takahashi K, Yamanaka S. Induction of pluripotent stem cells from mouse embryonic and adult fibroblast cultures by defined factors. Cell 2006; 126: 663-76.

6. Yu J, Vodyanik MA, Smuga-Otto K, et al. Induced pluripotent stem cell lines derived from human somatic cells. Science 2007; 318: 1917-20.

7. Yamanaka S, Blau HM. Nuclear reprogramming to a pluripotent state by three approaches. Nature 2010; 465: 704-12.

8. Orkin SH, Hochedlinger K. Chromatin connections to pluripotency and cellular reprogramming. Cell 2011; 145: 835-50.

9. Liang G, Zhang Y. Embryonic stem cell and induced pluripotent stem cell: an epigenetic perspective. Cell Res 2013; 23: 49-69.

10. Gaspar-Maia A, Alajem A, Meshorer E, Ramalho-Santos M. Open chromatin in pluripotency and reprogramming. Nat Rev Mol Cell Biol 2011; 12: 36-47.

11. Apostolou E, Hochedlinger K. Chromatin dynamics during cellular reprogramming. Nature 2013; 502: 462-71.

12. Smallwood SA, Kelsey G. De novo DNA methylation: a germ cell perspective. Trends Genet 2012; 28: 33-42.

13. Oswald J, Engemann S, Lane N, et al. Active demethylation of the paternal genome in the mouse zygote. Curr Biol 2000; 10: 475-8. 
14. Morgan HD, Santos F, Green K, Dean W, Reik W. Epigenetic reprogramming in mammals. Hum Mol Genet 2005; 14 Spec No 1 R47-58.

15. Smallwood SA, Tomizawa S, Krueger F, et al. Dynamic CpG island methylation landscape in oocytes and preimplantation embryos. Nat Genet 2011; 43: 811-4.

16. Smith ZD, Chan MM, Mikkelsen TS, Gu H, Gnirke A, Regev A, Meissner A. A unique regulatory phase of DNA methylation in the early mammalian embryo. Nature 2012; 484: 339-44.

17. Beard C, Li E, Jaenisch R. Loss of methylation activates Xist in Somatic but not in embryonic cells. Genes Dev 1995; 9: 2325-34.

18. Li E, Beard C, Jaenisch R. Role for DNA methylation in genomic imprinting. Nature 1993; 366: 362-5.

19. Li E, Bestor TH, Jaenisch R. Targeted mutation of the DNA methyltransferase gene results in embryonic lethality. Cell 1992; 69 915-26.

20. Okano M, Bell DW, Haber DA, Li E. DNA methyltransferases Dnmt3a and Dnmt3b are essential for de novo methylation and mammalian development. Cell 1999; 99: 247-57.

21. Hou P, Li Y, Zhang X, et al. Pluripotent stem cells induced from mouse somatic cells by small-molecule compounds. Science 2013; 341: 651-4.

22. Mikkelsen TS, Hanna J, Zhang X, et al. Dissecting direct reprogramming through integrative genomic analysis. Nature 2008; 454: 49-55.

23. Park IH, Zhao R, West JA, et al. Reprogramming of human somatic cells to pluripotency with defined factors. Nature 2008; 451: 141-6.

24. Lister R, Pelizzola M, Kida YS, et al. Hotspots of aberrant epigenomic reprogramming in human induced pluripotent stem cells. Nature 2011; 471: 68-73.

25. Ziller MJ, Muller F, Liao J, et al. Genomic distribution and in ter-sample variation of non-CpG methylation across human cell types. PLoS Genet 2011; 7: e1002389.

26. Ohi Y, Qin H, Hong C, et al. Incomplete DNA methylation underlies a transcriptional memory of somatic cells in human iPS cells. Nat Cell Biol 2011; 13: 541-9.

27. Nishino K, Toyoda M, Yamazaki-Inoue M, Fukawatase Y, Chikaza wa E, Sakaguchi H, Akutsu H, Umezawa A. DNA methylation dy namics in human induced pluripotent stem cells over time. PLoS Genet 2011; 7: e1002085.

28. Plasschaert RN, Bartolomei MS. Genomic imprinting in development, growth, behavior and stem cells. Development 2014; 141: 1805-13.

29. Wernig $M$, Meissner A, Foreman R, Brambrink T, Ku M Hochedlinger K, Bernstein BE, Jaenisch R. In vitro reprogramming of fibroblasts into a pluripotent ES-cell-like state. Nature 2007; 448: 318-24

30. Pick M, Stelzer Y, Bar-Nur O, Mayshar Y, Eden A, Benvenisty N. Clone- and gene-specific aberrations of parental imprinting in human induced pluripotent stem cells. Stem Cells 2009; 27: 2686 90.

31. Takikawa S, Ray C, Wang X, Shamis Y, Wu TY, Li X. Genomic imprinting is variably lost during reprogramming of mouse iPS cells. Stem Cell Res 2013; 11: 861-73.

32. Hiura H, Toyoda M, Okae H, et al. Stability of genomic imprinting in human induced pluripotent stem cells. BMC Genet 2013; 14: 32.

33. Liu L, Luo GZ, Yang W, et al. Activation of the imprinted DIk1-Dio3 region correlates with pluripotency levels of mouse stem cells. J Biol Chem 2010; 285: 19483-90.

34. Stadtfeld M, Apostolou E, Akutsu H, et al. Aberrant silencing of imprinted genes on chromosome 12qF1 in mouse induced pluripotent stem cells. Nature 2010; 465: 175-81.

35. Carey BW, Markoulaki S, Hanna JH, et al. Reprogramming factor stoichiometry influences the epigenetic state and biological properties of induced pluripotent stem cells. Cell Stem Cell 2011; 9: 588-98.

36. Stadtfeld M, Apostolou E, Ferrari F, et al. Ascorbic acid prevents loss of Dlk1-Dio3 imprinting and facilitates generation of all-iPS cell mice from terminally differentiated B cells. Nat Genet 2012; 44: 398-405, S1-2.

37. Stadtfeld M, Maherali N, Breault DT, Hochedlinger K. Defining molecular cornerstones during fibroblast to iPS cell reprogramming in mouse. Cell Stem Cell 2008; 2: 230-40.
38. Navarro P, Avner P. When X-inactivation meets pluripotency: an intimate rendezvous. FEBS Lett 2009; 583: 1721-7.

39. Cheung AY, Horvath LM, Grafodatskaya D, Pasceri P, Weksberg R, Hotta A, Carrel L, Ellis J. Isolation of MECP2-null Rett Syndrome patient hiPS cells and isogenic controls through X-chromosome inactivation. Hum Mol Genet 2011; 20: 2103-15.

40. Pomp O, Dreesen O, Leong DF, Meller-Pomp O, Tan TT, Zhou F, Colman $\mathrm{A}$. Unexpected $\mathrm{X}$ chromosome skewing during culture and reprogramming of human somatic cells can be alleviated by exogenous telomerase. Cell Stem Cell 2011; 9: 156-65.

41. Kim KY, Hysolli E, Park IH. Neuronal maturation defect in induced pluripotent stem cells from patients with Rett syndrome. Proc Natl Acad Sci U S A 2011; 108: 14169-74.

42. Marchetto MC, Carromeu C, Acab A, et al. A model for neural development and treatment of Rett syndrome using human induced pluripotent stem cells. Cell 2010; 143: 527-39.

43. Tchieu J, Kuoy E, Chin MH, et al. Female human iPSCs retain an inactive X chromosome. Cell Stem Cell 2010; 7: 329-42.

44. Tomoda K, Takahashi K, Leung K, et al. Derivation conditions im pact $X$-inactivation status in female human induced pluripotent stem cells. Cell Stem Cell 2012; 11: 91-9.

45. Bagci H, Fisher AG. DNA demethylation in pluripotency and reprogramming: the role of tet proteins and cell division. Cell Stem Cell 2013; 13: 265-9.

46. Doege CA, Inoue K, Yamashita T, et al. Early-stage epigenetic modification during somatic cell reprogramming by Parp1 and Tet2. Nature 2012; 488: 652-5.

47. Gao Y, Chen J, Li K, et al. Replacement of Oct4 by Tet1 during iPSC induction reveals an important role of DNA methylation and hydroxymethylation in reprogramming. Cell Stem Cell 2013; 12: 453 69.

48. Costa Y, Ding J, Theunissen TW, et al. NANOG-dependent function of TET1 and TET2 in establishment of pluripotency. Nature 2013; 495: 370-4.

49. Wang T, Wu H, Li Y, et al. Subtelomeric hotspots of aberrant 5-hydroxymethylcytosine-mediated epigenetic modifications during reprogramming to pluripotency. Nat Cell Biol 2013; 15: 700-11.

50. Hu X, Zhang L, Mao SQ, et al. Tet and TDG mediate DNA demethylation essential for mesenchymal-to-epithelial transition in somatic cell reprogramming. Cell Stem Cell 2014; 14: 512-22.

51. Swygert SG, Peterson CL. Chromatin dynamics: Interplay between remodeling enzymes and histone modifications. Biochim Biophys Acta 2014; 1839: 728-36

52. Koche RP, Smith ZD, Adli M, Gu H, Ku M, Gnirke A, Bernstein BE, Meissner A. Reprogramming factor expression initiates widespread targeted chromatin remodeling. Cell Stem Cell 2011; 8: 96-105.

53. Ringrose L, Paro R. Epigenetic regulation of cellular memory by the Polycomb and Trithorax group proteins. Annu Rev Genet 2004; 38 : 413-43.

54. Dou Y, Milne TA, Ruthenburg AJ, Lee S, Lee JW, Verdine GL, Allis CD, Roeder RG. Regulation of MLL1 H3K4 methyltransferase activity by its core components. Nat Struct Mol Biol 2006; 13: 713-9.

55. Ang YS, Tsai SY, Lee DF, et al. Wdr5 mediates self-renewal and reprogramming via the embryonic stem cell core transcriptional network. Cell 2011; 145: 183-97.

56. Kidder BL, Hu G, Yu ZX, Liu C, Zhao K. Extended self-renewal and accelerated reprogramming in the absence of Kdm5b. Mol Cell Biol 2013; 33: 4793-810.

57. Liang G, He J, Zhang Y. Kdm2b promotes induced pluripotent stem cell generation by facilitating gene activation early in reprogram ming. Nat Cell Biol 2012; 14: 457-66.

58. Wang T, Chen K, Zeng X, et al. The histone demethylases Jhdm1a/1b enhance somatic cell reprogramming in a vitamin-C-dependent manner. Cell Stem Cell 2011; 9: 575-87.

59. Onder TT, Kara N, Cherry A, et al. Chromatin-modifying enzymes as modulators of reprogramming. Nature 2012; 483: 598-602.

60. Buganim Y, Faddah DA, Cheng AW, et al. Single-cell expression analyses during cellular reprogramming reveal an early stochastic and a late hierarchic phase. Cell 2012; 150: 1209-22.

61. Pereira CF, Piccolo FM, Tsubouchi T, et al. ESCs require PRC2 to direct the successful reprogramming of differentiated cells toward pluripotency. Cell Stem Cell 2010; 6: 547-56. 
62. Ding X, Wang X, Sontag S, Oin J, Wanek P, Lin O, Zenke M. The polycomb protein Ezh2 impacts on induced pluripotent stem cell generation. Stem Cells Dev 2014; 23: 931-40.

63. Fragola G, Germain PL, Laise $P$, et al. Cell reprogramming requires silencing of a core subset of polycomb targets. PLoS Genet 2013; 9: e1003292.

64. Mansour AA, Gafni O, Weinberger L, et al. The H3K27 demethylase Utx regulates somatic and germ cell epigenetic reprogramming. Nature 2012; 488: 409-13.

65. Chen J, Liu H, Liu J, et al. H3K9 methylation is a barrier during so matic cell reprogramming into iPSCs. Nat Genet 2013; 45: 34-42.

66. Epsztejn-Litman S, Feldman N, Abu-Remaileh M, et al. De novo DNA methylation promoted by G9a prevents reprogramming of embryonically silenced genes. Nat Struct Mol Biol 2008; 15: 1176-83.

67. Soufi A, Donahue G, Zaret KS. Facilitators and impediments of the pluripotency reprogramming factors' initial engagement with the genome. Cell 2012; 151: 994-1004.

68. Sridharan R, Gonzales-Cope M, Chronis C, et al. Proteomic and genomic approaches reveal critical functions of H3K9 methylation and heterochromatin protein-1gamma in reprogramming to pluripotency. Nat Cell Biol 2013; 15: 872-82.

69. Das PP, Shao Z, Beyaz S, et al. Distinct and combinatorial functions of Jmjd2b/Kdm4b and Jmjd2c/Kdm4c in mouse embryonic stem cell identity. Mol Cell 2014; 53: 32-48.

70. Singhal N, Graumann J, Wu G, et al. Chromatin-Remodeling Components of the BAF Complex Facilitate Reprogramming. Cell 2010; 141: 943-55.

71. Kleger A, Mahaddalkar PU, Katz SF, et al. Increased reprogramming capacity of mouse liver progenitor cells, compared with differentiated liver cells, requires the BAF complex. Gastroenterology 2012; 142: 907-17.

72. Wang L, Du Y, Ward JM, et al. INO80 facilitates pluripotency gene activation in embryonic stem cell self-renewal, reprogramming, and blastocyst development. Cell Stem Cell 2014; 14: 575-91.

73. Gaspar-Maia A, Alajem A, Polesso F, et al. Chd1 regulates open chromatin and pluripotency of embryonic stem cells. Nature 2009; 460: 863-8.

74. Hu G, Wade PA. NuRD and pluripotency: a complex balancing act. Cell Stem Cell 2012; 10: 497-503.

75. Huangfu D, Maehr R, Guo W, Eijkelenboom A, Snitow M, Chen AE, Melton DA. Induction of pluripotent stem cells by defined factors is greatly improved by small-molecule compounds. Nat Biotechnol 2008; 26: 795-7.

76. Huangfu D, Osafune K, Maehr R, Guo W, Eijkelenboom A, Chen S, Muhlestein W, Melton DA. Induction of pluripotent stem cells from primary human fibroblasts with only Oct4 and Sox2. Nat Biotechnol 2008; 26: 1269-75.

77. Liang G, Taranova O, Xia K, Zhang Y. Butyrate promotes induced pluripotent stem cell generation. J Biol Chem 2010; 285: 25516-21.

78. Mali P, Chou BK, Yen J, et al. Butyrate greatly enhances derivation of human induced pluripotent stem cells by promoting epigenetic remodeling and the expression of pluripotency-associated genes. Stem Cells 2010; 28: 713-20.

79. Lee MR, Prasain N, Chae HD, Kim YJ, Mantel C, Yoder MC, Broxmeyer HE. Epigenetic regulation of NANOG by miR-302 cluster-MBD2 completes induced pluripotent stem cell reprogramming. Stem Cells 2013; 31: 666-81.

80. Lu Y, Loh YH, Li H, et al. Alternative splicing of MBD2 supports self-renewal in human pluripotent stem cells. Cell Stem Cell 2014; 15: 92-101.

81. Rais Y, Zviran A, Geula S, et al. Deterministic direct reprogramming of somatic cells to pluripotency. Nature 2013; 502: 65-70.

82. Luo $M$, Ling $T$, Xie $W$, et al. NuRD blocks reprogramming of mouse somatic cells into pluripotent stem cells. Stem Cells 2013; 31: 1278-86.

83. dos Santos RL, Tosti L, Radzisheuskaya A, Caballero IM, Kaji K, Hendrich B, Silva JC. MBD3/NuRD facilitates induction of pluripotency in a context-dependent manner. Cell Stem Cell 2014; 15: 102-10.

84. Shinagawa T, Takagi T, Tsukamoto D, et al. Histone variants enriched in oocytes enhance reprogramming to induced pluripotent stem cells. Cell Stem Cell 2014; 14: 217-27.
85. Barrero MJ, Sese B, Kuebler B, Bilic J, Boue S, Martí M, Izpisua Belmonte JC. Macrohistone variants preserve cell identity by preventing the gain of $\mathrm{H} 3 \mathrm{~K} 4 \mathrm{me} 2$ during reprogramming to pluripotency. Cell Rep 2013; 3: 1005-11.

86. Barrero MJ, Sese B, Marti M, Izpisua Belmonte JC. Macro histone variants are critical for the differentiation of human pluripotent cells. J Biol Chem 2013; 288: 16110-16.

87. Gaspar-Maia A, Qadeer ZA, Hasson D, et al. MacroH2A histone variants act as a barrier upon reprogramming towards pluripotency. Nat Commun 2013; 4: 1565.

88. Pasque V, Radzisheuskaya A, Gillich A, Halley-Stott RP, Panamarova $M$, Zernicka-Goetz M, Surani MA, Silva JC. Histone variant macroH2A marks embryonic differentiation in vivo and acts as an epigenetic barrier to induced pluripotency. J Cell Sci 2012; 125 : 6094-104.

89. Chang CC, Gao S, Sung LY, Corry GN, Ma Y, Nagy ZP, Tian XC, Rasmussen TP. Rapid elimination of the histone variant MacroH2A from somatic cell heterochromatin after nuclear transfer. Cell Reprogram 2010; 12: 43-53.

90. Gao X, Tate P, Hu P, Tjian R, Skarnes WC, Wang Z. ES cell pluripotency and germ-layer formation require the SWI/SNF chromatin remodeling component BAF250a. Proc Natl Acad Sci U S A 2008; 105: 6656-61.

91. Ho L, Ronan J, Wu J, et al. An embryonic stem cell chromatin remodeling complex, esBAF, is essential for embryonic stem cell self-renewal and pluripotency. Proc Natl Acad Sci U S A 2009; 106: 5181-6.

92. Reynolds N, Salmon-Divon M, Dvinge H, et al. NuRD-mediated deacetylation of $\mathrm{H} 3 \mathrm{~K} 27$ facilitates recruitment of Polycomb Repressive Complex 2 to direct gene repression. EMBO J 2012; 31: 593-605.

93. Kaji K, Caballero IM, MacLeod R, Nichols J, Wilson VA, Hendrich B. The NURD component Mbd3 is required for pluripotency of embryonic stem cells. Nat Cell Biol 2006; 8: 285-92.

94. Dovey OM, Foster CT, Cowley SM. Histone deacetylase 1 (HDAC1), but not HDAC2, controls embryonic stem cell differentiation. Proc Natl Acad Sci U S A 2010; 107: 8242-7.

95. Fazzio TG, Huff JT, Panning B. An RNAi screen of chromatin proteins identifies Tip60-p400 as a regulator of embryonic stem cell identity. Cell 2008; 134: 162-74.

96. Dey BK, Stalker L, Schnerch A, Bhatia M, Taylor-Papidimitriou J, Wynder C. The histone demethylase KDM5b/JARID1b plays a role in cell fate decisions by blocking terminal differentiation. Mol Cell Biol 2008; 28: 5312-27.

97. Xie L, Pelz C, Wang W, Bashar A, Varlamova O, Shadle S, Impey S. KDM5B regulates embryonic stem cell self-renewal and represses cryptic intragenic transcription. EMBO J 2011; 30: 1473-84.

98. Boyer LA, Plath K, Zeitlinger J, et al. Polycomb complexes repress developmental regulators in murine embryonic stem cells. Nature 2006; 441: 349-53.

99. Melcer S, Hezroni H, Rand E, Nissim-Rafinia M, Skoultchi A, Stewart CL, Bustin M, Meshorer E. Histone modifications and lamin A regulate chromatin protein dynamics in early embryonic stem cell differentiation. Nat Commun 2012; 3: 910.

100. Yamamizu K, Fujihara M, Tachibana M, et al. Protein kinase A determines timing of early differentiation through epigenetic regulation with G9a. Cell Stem Cell 2012; 10: 759-70.

101. Matsui T, Leung D, Miyashita H, et al. Proviral silencing in embryonic stem cells requires the histone methyltransferase ESET. Nature 2010; 464: 927-31.

102. Rowe HM, Friedli M, Offner S, Verp S, Mesnard D, Marquis J, Aktas T, Trono D. De novo DNA methylation of endogenous retroviruses is shaped by KRAB-ZFPs/KAP1 and ESET. Development 2013; 140: 519-29.

103. Bilodeau S, Kagey MH, Frampton GM, Rahl PB, Young RA. SetDB1 contributes to repression of genes encoding developmental regulators and maintenance of ES cell state. Genes Dev 2009; 23: 2484-9.

104. Kang YK. SETDB1 in Early Embryos and Embryonic Stem Cells. Curr Issues Mol Biol 2014; 17: 1-10.

105. Lohmann F, Loureiro J, Su H, et al. KMT1E mediated H3K9 methylation is required for the maintenance of embryonic stem cells 
by repressing trophectoderm differentiation. Stem Cells 2010; 28: 201-12.

106. Yuan P, Han J, Guo G, et al. Eset partners with Oct4 to restrict extraembryonic trophoblast lineage potential in embryonic stem cells. Genes Dev 2009; 23: 2507-20.

107. Bulut-Karslioglu A, De La Rosa-Velazquez IA, Ramirez F, et al. Suv39h-Dependent H3K9me3 Marks Intact Retrotransposons and Silences LINE Elements in Mouse Embryonic Stem Cells. Mol Cell 2014; 55: 277-90.

108. Loh YH, Zhang W, Chen X, George J, Ng HH. Jmjd1a and Jmjd2C histone $\mathrm{H} 3$ Lys 9 demethylases regulate self-renewal in embryonic stem cells. Genes Dev 2007; 21: 2545-57.

109. Barry ER, Krueger W, Jakuba CM, Veilleux E, Ambrosi DJ, Nelson CE, Rasmussen TP. ES cell cycle progression and differentiation require the action of the histone methyltransferase Dot1l. Stem Cells 2009; 27: 1538-47.

110. Jones B, Su H, Bhat A, et al. The histone H3K79 methyltransferase Dot1l is essential for mammalian development and heterochromatin structure. PLoS Genet 2008; 4: e1000190.

\section{Address for correspondence}

\section{Urszula Oleksiewicz}

Department of Cancer Immunology

The Greater Poland Cancer Centre

Garbary 15

61-866 Poznan, Poland

e-mail: u.oleksiewicz@gmail.com 